\title{
Cutoff points in STOP-Bang questionnaire for obstructive sleep apnea
}

\author{
Pontos de corte no STOP-Bang para apneia obstrutiva do sono \\ Jose Apolinário Silva NEVES JUNIOR', Ana Paula Andrade FERNANDES', Maria Angela TARDELLI', \\ Américo Massafuni YAMASHITA (in memoriam)', Sônia Maria Pereira Guimarães Togeiro MOURA², \\ Sérgio TUFIK², Helga Cristina Almeida da SILVA'
}

\begin{abstract}
Background: Obstructive Sleep Apnea Syndrome (OSAS) is a public health problem of high prevalence and impacts on quality of life, anesthetic complications and cardiovascular diseases. In view of the difficulty in accessing the polysomnography, it is necessary to validate other methods for OSAS diagnostic screening in clinical practice in our country, such as the STOP-Bang questionnaire. Objective: To validate the STOP-Bang questionnaire in Brazilians and evaluate optimal cutoff points. Methods: After translation and back-translation, STOP-Bang questionnaire was applied to 71 individuals previously submitted to polysomnography and classified into control, mild, moderate or severe OSAS. Results: The majority of patients was male (59.2\%), white (79\%), aged $48.9 \pm 13.9$ years, and with neck circumference $>40$ centimeters (73.8\%). STOP-Bang score was higher in OSAS mild (median/inter-quartis 25-75\%: 5/3.5-6), moderate (4.5/4-5) and severe (5/4-6), versus control (2.5/1-4). The receiver operating characteristic (ROC) curve indicate that scores 3,4 and 6 , present the best specificity values (100, 80 and 92.9\%) with acceptable sensitivity (60,66.7 and 50\%) in the mild, moderate and severe OSAS subgroups, respectively. In OSAS group analysis (Apnea Hypopnea Index [AHI] $\geq 5,<15, \geq 15-<30, \geq 30$ ), STOP-Bang cutoff point of 6 was optimal to detect OSAS. Conclusion: STOP-Bang Brazilian version identified OSAS patients with lower sensitivity and higher specificity compared to previous studies. Different cutoff points would improve the performance to detect patients with more severe OSAS.
\end{abstract}

Keywords: Obstructive Sleep Apnea; Polysomnography; Surveys and Questionnaires.

\section{RESUMO}

Introdução: A Síndrome da Apneia Obstrutiva do Sono (SAOS) é um problema de saúde pública de alta prevalência e com impacto na qualidade de vida, complicações anestésicas e doenças cardiovasculares. Diante da dificuldade de acesso à realização da polissonografia, é necessário validar outros métodos para a triagem diagnóstica da SAOS na prática clínica no cenário brasileiro, como o questionário STOP-Bang. Objetivos: Validar o questionário STOP-Bang em brasileiros e avaliar os melhores pontos de corte. Método: Após tradução e retrotradução, o STOP-Bang foi aplicado em 71 indivíduos previamente submetidos à polissonografia e classificados em controles e em SAOS leve, moderada e grave. Resultados: A maioria da amostra foi de homens (59,2\%), com 48,9 $\pm 13,9$ anos, brancos (79\%) e com circunferência do pescoço $>40 \mathrm{~cm}$ (73,8\%). O escore STOP-Bang foi maior na SAOS leve (mediana/interquartis 25-75\%: 5/3,5-6), moderada (4,5/4-5) e grave (5/4-6) versus controles (2,5/1-4). A Curva Característica de Operação do Receptor (ROC) indicou que os escores 3, 4 e 6 apresentam os melhores valores de especificidade (100, 80 e 92,9\%) e sensibilidade aceitável (60, 66,7 e 50\%) nos subgrupos de SAOS leve, moderada e grave, respectivamente. Na análise da amostra com SAOS (IAH ] $\geq 5,<15, \geq 15-<30, \geq 30$ ), o ponto de corte de 6 no STOP-Bang detectou melhor a SAOS. Conclusão: A versão brasileira do STOP-Bang identificou pacientes apneicos com menor sensibilidade e maior especificidade em relação a estudos anteriores. Diferentes pontos de corte melhorariam o desempenho para detectar pacientes com SAOS mais grave.

Palavras-chave: Apneia Obstrutiva do Sono; Polissonografia; Inquéritos e Questionários.

\footnotetext{
1 Universidade Federal de São Paulo, Escola Paulista de Medicina, Department of Surgery, Discipline of Anesthesiology, Pain and Intensive Care, São Paulo SP, Brazil. Universidade Federal de São Paulo, Escola Paulista de Medicina, Department of Psychobiology, Sleep and Respiratory Divisions, São Paulo SP, Brazil.

Jose Apolinário Silva NEVES JUNIOR (iD https://orcid.org/0000-0003-1068-0647; Ana Paula Andrade FERNANDES (D) https://orcid.org/0000-0003-3130-3146; Maria Angela TARDELLI (D) https://orcid.org/0000-0001-8596-2791; Américo Massafuni YAMASHITA (in memoriam);

Sônia Maria Pereira Guimarães Togeiro MOURA (DD https://orcid.org/0000-0001-7103-9007; Sérgio TUFIK (D) https://orcid.org/0000-0002-4012-4951;

Helga Cristina Almeida da SILVA (D) https://orcid.org/0000-0002-9372-7019

Correspondence: Helga Cristina Almeida da SILVA; E-mail: halsilva@uol.com.br

Conflict of interest: There is no conflict of interest to declare.
}

Support: This study was financed in part by the Coordenação de Aperfeiçoamento de Pessoal de Nivel Superior - Brasil (CAPES) - Finance Code 001, Fundação de Amparo à Pesquisa do Estado de São Paulo (FAPESP), Associação Fundo de Incentivo à Pesquisa (AFIP) and Conselho Nacional de Desenvolvimento Científico e Tecnológico (CNPq).

Received on April 24, 2019; Received in its final form on February 20, 2020; Accepted on April 20, 2020.

Authors' contributions: Neves Junior JAS and Fernandes APA: data acquisition, analysis and interpretation of data, preparation of the article, final approval of the submitted version. Tardelli MA, Yamashita AM, Moura SMPGT, and Tufik S: conception and design of the study, critical review of the article for important intellectual content, final approval of the submitted version. Silva HCA: conception and design of the study, analysis and interpretation of data, preparation of the article, final approval of the submitted version. 


\section{INTRODUCTION}

The Obstructive Sleep Apnea is characterized by recurrent episodes of respiratory pause with duration greater than or equal to 10 seconds, with Apnea Hypopnea Index (AHI) of five or more events/hour, due to partial or complete occlusion of the upper airway causing reduction or cessation of inspiratory airflow ${ }^{1}$. When this condition is accompanied by symptoms, it is called Obstructive Sleep Apnea Syndrome (OSAS) $)^{1}$. This is the most common sleep respiratory disorder, which has had a significant increase in recent decades. In the epidemiologic study of OSAS held in São Paulo, Brazil, Tufik et al. found a prevalence of $32.8 \%$ in a population-based sam$\mathrm{ple}^{2}$. Since these events occur during sleep, approximately $82 \%$ of men and $93 \%$ of women may not be aware they have the condition and are not detected ${ }^{3}$.

Polysomnography is the gold standard to diagnosis of OSAS and determine the severity through of the AHI using the criteria of the International Classification of Sleep Disorders 2 (ICSD-2) $)^{1,4}$. However, the availability of the polysomnography study is limited in some countries, making the process lengthy, besides being cumbersome and expensive; in some cases, there is a delay of more than 10 years between the examination and onset of symptoms ${ }^{5,6}$. Simplified methods, such as cardiorespiratory record for home use, have been increasingly used for patients with high likelihood of OSA and have a good diagnostic agreement with conventional polysomnography ${ }^{7}$, but access to these diagnostic methods remains limited ${ }^{7,8}$.

Given the high prevalence of OSAS and its socio-economic impacts, associated with the difficulty of performing polysomnography and also the home record, it is clinically relevant the validation of another simple and reliable screening test ${ }^{7,8}$. Specific questionnaires have been developed to identify patients at risk for OSA in clinical practice, as a more economical alternative when compared to polysomnography; among them, the STOP-Bang has been indicated by the methodological simplicity and superiority in the predictive value ${ }^{8,9}$. This Canadian mnemonic acronym questionnaire includes characteristic signs and symptoms of sleep-disordered breathing, in the self-report format, and takes about one minute to complete. It consists of eight questions to STOP (Snoring, daytime Tiredness, Observed apnea, high blood Pressure) and Bang (Body mass index, Age, Neck circumference, Gender) with two response options (yes or no); three positive responses indicates a risk of OSAS, with sensitivities of 83.9, 92.9 and $100 \%$ in surgical patients and 90, 94 and 96\% in sleep clinics, for AHI >5, >15 and >30, respectively ${ }^{10,11}$.

This study aimed to perform translation, back-translation and validation of the questionnaire STOP-Bang to diagnostic screening of OSAS in a Brazilian sample submitted to polysomnography, analyzing additionally the adequacy of the proposed cutoff points of this questionnaire in this group.

\section{METHODS}

This study was performed with compliance with ethical standards. The Research Ethics Committee of the Universidade Federal de São Paulo (Unifesp)/ Escola Paulista de Medicina (EPM), approved this study and all participants, from the Sleep Respiratory Disorders Clinic of Unifesp, have signed the free and informed consent declaration. Initially, the STOP-Bang questionnaire (Figure 1) was translated from English to Portuguese by two independent translators fluent in English, resulting in two versions in Portuguese. After consensus among translators, a third version was developed in Portuguese. This third version was subsequently translated into English, compared to the original questionnaire and considered similar, then completing the process of reverse translation. After that, the third Portuguese version was used in 10 patients diagnosed with OSAS according to ICSD-2 criteria, to evaluate the acceptability and understanding, which were considered satisfactory (Figures 2 and 3 ).

Inclusion criteria for this study were the age $\geq 18$ years, clinical suspicion of OSAS and realization of polysomnography to fulfill the criteria of OSAS according to ICSD-2. Exclusion criteria were treatment started for OSAS or living alone (no one to report symptoms during sleep). Considering the work of Chung et al., in which sensitivity of STOP-Bang ranged from 83.6 to $100 \%$, and specificity from 37 to $56.4 \%$, to detect at least a $50 \%$ correlation between the STOP-Bang score and polysomnography, with a significance level of 0.05 , it was estimated that 80 individuals would be needed ${ }^{10}$. However, the periodic statistical analysis of the data showed that, when it reached the number of 71 questionnaires filled out correctly, the data were sufficient to complete the study, as an at least $50 \%$ correlation was reached.

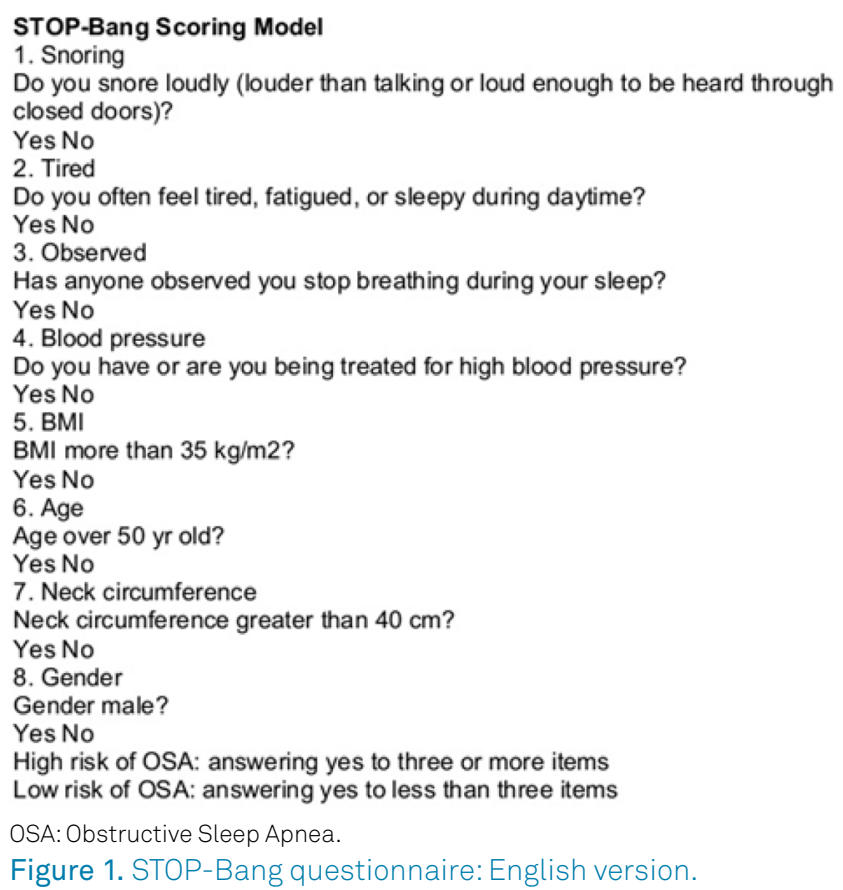




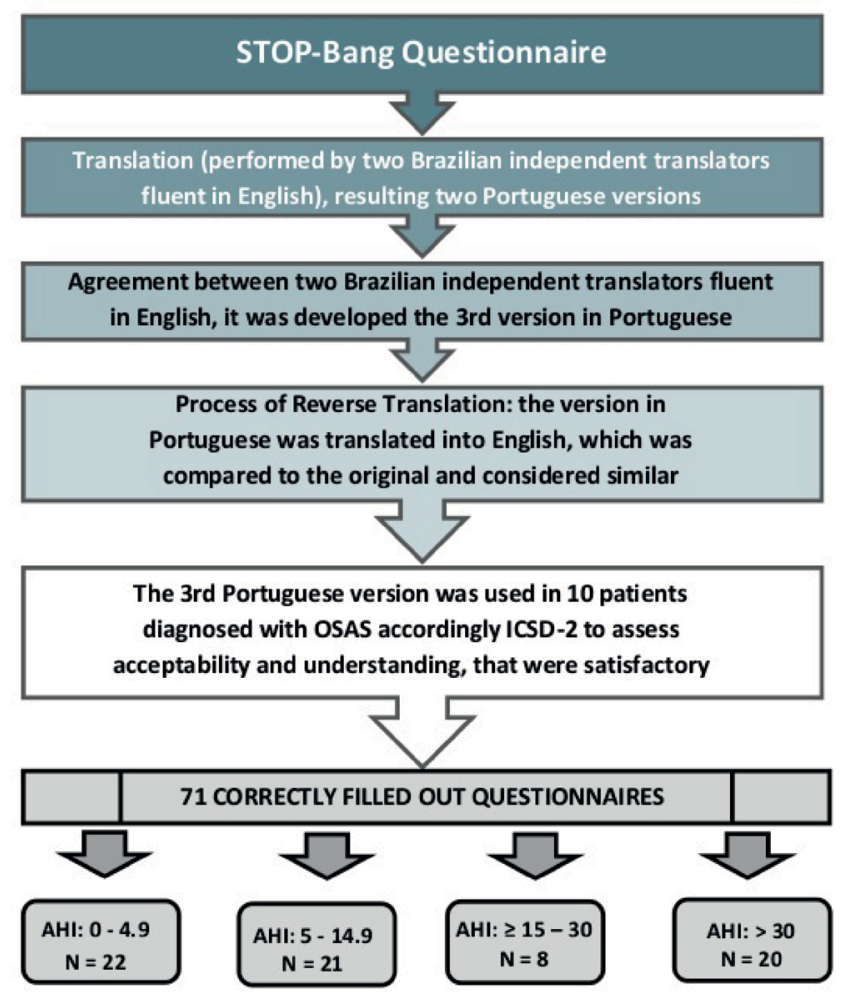

Figure 2. Flowchart of the study.

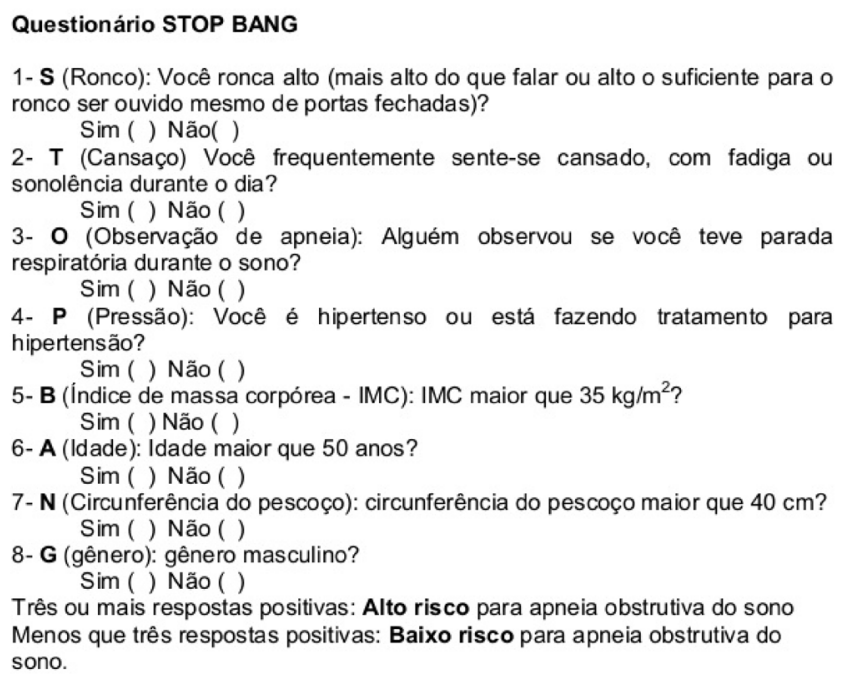

1- S (Ronco): Você ronca alto (mais alto do que falar ou alto o suficiente para o ronco ser ouvido mesmo de portas fechadas)? Sim ( ) Não( )

2- T (Cansaço) Você frequentemente sente-se cansado, com fadiga ou sonolência durante o dia?$$
\text { Sim ( ) Não ( ) }
$$

3- O (Observação de apneia): Alguém observou se você teve parada respiratória durante o sono?

Sim ( ) Não ( )

4- P (Pressão): Você é hipertenso ou está fazendo tratamento para hipertensão? Sim ( ) Não ( )

5- B (Índice de massa corpórea - IMC): IMC maior que $35 \mathrm{~kg} / \mathrm{m}^{2}$ ? Sim ( ) Não ( )

6- A (Idade): Idade maior que 50 anos?

Sim ( ) Não ( )

7- N (Circunferência do pescoço): circunferência do pescoço maior que $40 \mathrm{~cm}$ ? Sim ( ) Não ( )

8- G (gênero): gênero masculino?

Sim ( ) Não ( )

Três ou mais respostas positivas: Alto risco para apneia obstrutiva do sono Menos que três respostas positivas: Baixo risco para apneia obstrutiva do sono.

Figure 3. STOP-Bang questionnaire: Portuguese version.

The polysomnography was performed at the Sleep's Institute of Unifesp/EPM, for one night, during the usual sleep time of the subject, using digital system (EMBLA S7000, Embla Systems, Inc., Broomfield, CO., USA). The electroencephalogram, arousals, and respiratory events related to sleep were scored according to the criteria of the American Academy of Sleep Medicine (AASM) Manual for Scoring Sleep and Associated Events ${ }^{12}$. All patients underwent interview and polysomnography, being diagnosed as controls or patients with OSAS according to ICSD-2 criteria proposed by the $\mathrm{AASM}^{4,12}$. Patients with AHI below five formed the control group ( $\mathrm{n}=22 ; 30.9 \%)$. Participants with mild OSAS had AHI between five and $14.9(\geq 5$ to $<15)$ associated with the presentation of at least one of the following complaints: loud snoring, daytime sleepiness or fatigue, and breathing interruptions during sleep ( $\mathrm{n}=21 ; 29.57 \%)$. Individuals with AHI values between 15 and $30(\geq 15$ to $\leq 30)$ were classified as moderate OSA, regardless of complaints $(n=8 ; 11.26 \%)$. Those with AHI $>30$ formed the severe apnea group $(n=20 ; 28.16 \%)^{2,4,13}$. The variables of this study were: age, sex, height, weight, neck circumference, AHI, ethnicity, civil status, educational level, medications, personal and family history/antecedents.

Data were stored on the computer and analyzed by SPSS Statistics version 21 statistical program. The exploratory analysis by K-S distance test classified the normality data. Continuous variables with normal distribution were described as mean and standard deviation. The median and interquartiles was used for continuous variables with nonparametric distribution and $\mathrm{n}(\%)$ for nominal variables. It was calculated the confidential interval of $95 \%$ for accuracy of assessment for continuous measures. It was considered value $\alpha \leq 0.05$ (p) to the possibility of type I error. The differences between groups were calculated by tests: Pearson's $\chi^{2}$, Student's t-test for independent samples, Fisher, Z for proportions with $\mathrm{p}$ value adjusted by the Bonferroni method, Mann-Whitney, ANOVA, Kruskal-Wallis, and Tukey posttest. The Spearman correlation test evaluated the validation criteria; coefficient (r) was classified according $\mathrm{McGraw}^{14}$. The ROC curve and logistic regression determined the cutoff points for the STOP-Bang, area under the curve, sensitivity, specificity, predictive values, Odds Ratios and $95 \%$ confidence limit for diagnosis of OSAS in subgroups.

\section{RESULTS}

Of the 71 patients, most were men $(59.2 \%$; $n=42)$, white (79\%; $\mathrm{n}=56)$, in the fifth decade of life (48.9 \pm 13.9 years), with at least 11 years of school ( $35 \% ; n=25)$, and a neck circumference $(\mathrm{NC})$ greater than 40 centimeters $(\mathrm{cm})(53.5 \%$; $\mathrm{n}=38)$. The women had lower height values ( 1.58 vs. $1.72 \mathrm{~m}$; $\mathrm{p}=0.001$ for Mann-Whitney test), weight ( 69.4 vs. $87.6 \mathrm{~kg}$; $\mathrm{p}=0.001$ for Student's t-test for independent samples), NC (39 vs. $42 \mathrm{~cm}$; $\mathrm{p}=0.001$ for Mann-Whitney test), AHI (5.4 vs. 13.5; $\mathrm{p}=0.008$ for Mann-Whitney test) and STOP-Bang score (3 vs. $5 ; \mathrm{p}=0.002$ for Mann-Whitney test). Men and women were similar in age, BMI, presence of snoring, sleepiness, breathing pauses during sleep, hypertension and classification of the AHI. OSAS was the most common problem in family history (36.6\%), and pulmonary diseases were the most common personal antecedents $(25.3 \%)$.

The analysis of subgroups control and mild, moderate or severe OSAS, showed differences in the following 
quantitative parameters: patients from moderate OSAS subgroup were significantly older and patients from severe OSAS subgroup had higher values of weight and BMI (Table 1). There was no difference among the four groups regarding educational level ( $\mathrm{p}=0.75$, Kruskal-Wallis test). The STOP-Bang score was significantly higher in all subgroups with OSAS in relation of the control subgroup (Table 1). In relation to the qualitative parameters, compared to the control subgroup, the severe OSAS subgroup showed significantly higher frequencies of breathing pauses during sleep, snoring, and $\mathrm{NC}$ greater than $40 \mathrm{~cm}$, while the mild OSAS group had only significantly higher frequency of breathing pauses during sleep (Table 2).

A positive correlation was found between the STOP-Bang score and weight ( $r=0.522 ; \mathrm{p} \leq 0,01$; Spearman correlation test),
$\mathrm{NC}(\mathrm{r}=0.562 ; \mathrm{p} \leq 0,01$; Spearman correlation test), $\mathrm{AHI}(\mathrm{r}=0.598$; $\mathrm{p} \leq 0,01$; Spearman correlation test), and BMI ( $r=0.478$; $p \leq 0,01$; Spearman correlation test). AHI was positively correlated with age $(r=0.262 ; p=0.05$; Spearman correlation test), weight $(\mathrm{r}=0.399 ; \mathrm{p} \leq 0,01$; Spearman correlation test), $\mathrm{NC}(\mathrm{r}=0.331$; $\mathrm{p} \leq 0,01$; Spearman correlation test), and BMI ( $r=0.485 ; \mathrm{p} \leq 0,01$; Spearman correlation test). Median STOP-Bang questionnaire score was $\geq 5$ when the NC was greater than $40 \mathrm{~cm}$, or snoring, sleepiness, breathing pauses during sleep, and hypertension were present (Table 3). AHI was greater only with the presence of the variables of $\mathrm{NC}$ greater than $40 \mathrm{~cm}$, snoring and breathing pauses during sleep (Table 3).

In logistic regression, there was not relationship of cause and effect between the STOP-Bang score dichotomized (OSAS present or absent) and questionnaire components

Table 1. Minimum, maximum, and median values, standard deviation, and p-values of demographic, clinical and anatomical continuous variables of four groups $(n=71)$.

\begin{tabular}{|c|c|c|c|c|c|c|c|}
\hline & & Minimum & Maximum & Median & Average & Standard deviation & $p$-value \\
\hline \multirow{4}{*}{ Age (years) } & $\mathrm{AHI} 0-4,9$ & 18 & 80 & 35 & 41,6 & 15,3 & \multirow{4}{*}{$0,01 *$} \\
\hline & $\mathrm{AHI} 5-14,9$ & 34 & 82 & 52 & 52,5 & 11 & \\
\hline & $A H I \geq 15-30$ & 36 & 74 & 62,5 & $58^{\mathrm{a}}$ & 13,6 & \\
\hline & $\mathrm{AHI}>30$ & 30 & 71 & 48 & 49,5 & 11,9 & \\
\hline \multirow{4}{*}{ Weight (kilograms) } & AHI 0-4,9 & 41 & 120 & 68 & 66,9 & 17 & \multirow{4}{*}{$<0,01 *$} \\
\hline & AHI 5-14,9 & 45 & 102 & 82 & 80,3 & 15,3 & \\
\hline & $A H I \geq 15-30$ & 43 & 111 & 73 & 72,8 & 21,9 & \\
\hline & $A H I>30$ & 30 & 158 & 87,5 & $89,6^{a}$ & 28,7 & \\
\hline \multirow{4}{*}{ Height (meters) } & AHI 0-4,9 & 1,5 & 1,8 & 1,65 & 1,65 & 0,1 & \multirow{4}{*}{$0,462 \dagger$} \\
\hline & AHI 5-14,9 & 1,4 & 1,9 & 1,72 & 1,69 & 0,1 & \\
\hline & $A H I \geq 15-30$ & 1,6 & 1,8 & 1,67 & 1,67 & 0,1 & \\
\hline & $A H I>30$ & 1,5 & 1,8 & 1,67 & 1,66 & 0,1 & \\
\hline \multirow{4}{*}{ Neck circumference (cm) } & AHI 0-4,9 & 36 & 48 & 39 & 39,8 & 2,7 & \multirow{4}{*}{$0,07+$} \\
\hline & AHI 5-14,9 & 31 & 47 & 41 & 40,7 & 4,1 & \\
\hline & $A H I \geq 15-30$ & 32 & 53 & 41,5 & 41,3 & 5,8 & \\
\hline & $\mathrm{AHI}>30$ & 35 & 49 & 42,5 & 42,7 & 3,9 & \\
\hline \multirow{4}{*}{$\mathrm{AHI}$ (events/hour) } & AHI 0-4,9 & 0 & 4 & 1,8 & 1,7 & 1,5 & \multirow{4}{*}{$<0,001 \dagger$} \\
\hline & AHI 5-14,9 & 5 & 14 & 8,6 & 9 & 2,8 & \\
\hline & $A H I \geq 15-30$ & 15,4 & 25,4 & 18 & 19,1 & 3,6 & \\
\hline & $A H I>30$ & 32 & 110 & 61,9 & 62,7 & 21,3 & \\
\hline \multirow{4}{*}{$\mathrm{BMI}\left(\mathrm{kg} / \mathrm{m}^{2}\right)$} & AHI 0-4,9 & 15 & 37 & 24,5 & 24,5 & 4,9 & \multirow{4}{*}{$<0,001 \dagger$} \\
\hline & AHI 5-14,9 & 21,7 & 39 & 28 & 29 & 4,4 & \\
\hline & $A H I \geq 15-30$ & 15 & 41,3 & 26,5 & 26,1 & 7,9 & \\
\hline & $A H I>30$ & 22,6 & 61 & $32,6^{a}$ & 33,8 & 8,7 & \\
\hline \multirow{4}{*}{ STOP-Bang (score) } & AHI 0-4,9 & 0 & 7 & 2,5 & 2,6 & 1,7 & \multirow{4}{*}{$<0,001 \dagger$} \\
\hline & AHI 5-14,9 & 3 & 7 & $5^{a}$ & 4,6 & 1,3 & \\
\hline & $A H I \geq 15-30$ & 3 & 8 & $4,5^{a}$ & 5 & 1,5 & \\
\hline & $A H I>30$ & 3 & 8 & $5^{\mathrm{a}}$ & 5,1 & 1,4 & \\
\hline
\end{tabular}

AHI: Apnea Hypopnea Index; cm: centimeters; BMI: body mass index; kg/m²: kilograms per meter squared; ${ }^{2}$ vs. the control; ${ }^{\star}$ ANOVA with Tukey post-test; †Kruskal-Wallis test with Tukey post-test. In the AHI variable, all subgroups were different, the expected result in view of this being the criterion of separation of subgroups. 
Table 2. Evaluation of the qualitative variables of the four Apnea Hypopnea Index groups $(n=71)$.

\begin{tabular}{|c|c|c|c|c|c|c|c|c|c|c|}
\hline & & \multicolumn{2}{|c|}{ AHI 0-4,9 } & \multicolumn{2}{|c|}{ AHI 5-14,9 } & \multicolumn{2}{|c|}{$\mathrm{AHI} \geq 15-30$} & \multicolumn{2}{|c|}{$\mathrm{AHI}>30$} & \multirow{2}{*}{$p$-value* } \\
\hline & & $n$ & $\%$ & $n$ & $\%$ & $\mathrm{n}$ & $\%$ & $\mathrm{n}$ & $\%$ & \\
\hline \multirow{2}{*}{ Neck circumference } & $\leq 40 \mathrm{~cm}$ & 15 & 68,2 & 9 & 42,8 & 3 & 37,5 & 6 & 30 & \multirow{2}{*}{0,042} \\
\hline & $>40 \mathrm{~cm}$ & 7 & 31,8 & 12 & 57,2 & 5 & 62,5 & 14 & $70^{a}$ & \\
\hline \multirow{2}{*}{ Snoring } & Yes & 11 & 50 & 17 & 81 & 7 & 87,5 & 18 & $90^{\mathrm{a}}$ & \multirow{2}{*}{0,015} \\
\hline & No & 11 & 50 & 4 & 19 & 1 & 12,5 & 2 & 10 & \\
\hline \multirow{2}{*}{ Sleepiness } & Yes & 16 & 72,7 & 16 & 76,2 & 7 & 87,5 & 14 & 70 & \multirow{2}{*}{0,891} \\
\hline & No & 6 & 27,3 & 5 & 23,8 & 1 & 12,5 & 6 & 30 & \\
\hline \multirow{2}{*}{$\begin{array}{l}\text { Breathing pauses } \\
\text { during sleep }\end{array}$} & Yes & 5 & 22,7 & 16 & $76,2^{a}$ & 4 & 50 & 17 & $85^{a}$ & \multirow{2}{*}{$<0,001$} \\
\hline & No & 17 & 77,3 & 5 & 23,8 & 4 & 50 & 3 & 15 & \\
\hline \multirow{2}{*}{$\begin{array}{l}\text { Systemic arterial } \\
\text { hypertension }\end{array}$} & Yes & 5 & 22,7 & 9 & 42,9 & 3 & 37,5 & 9 & 45 & \multirow{2}{*}{0,416} \\
\hline & No & 17 & 77,3 & 12 & 57,1 & 5 & 62,5 & 11 & 55 & \\
\hline
\end{tabular}

AHI: Apnea Hypopnea Index; ${ }^{2} v s$. control group by $Z$ test for proportions with $p$-value adjusted by the Bonferroni method. *Fisher's exact test.

Table 3. Correlation between qualitative variables of the questionnaire and the STOP-Bang score or Apnea Hypopnea Index.

\begin{tabular}{|c|c|c|c|c|c|c|}
\hline & & \multirow{2}{*}{ Median } & \multirow{2}{*}{$p$-value } & \multirow{2}{*}{ OR } & \multicolumn{2}{|c|}{$95 \%$ confidence interval } \\
\hline & & & & & Inferior limit & Upper limit \\
\hline \multirow{2}{*}{ Neck circumference (>40 cm) } & STOP-Bang & 5 & $0,000 *$ & 2,675 & 1,658 & 4,317 \\
\hline & $\mathrm{AHI}$ & 14,7 & $0,007 \dagger$ & 1,018 & 0,999 & 1,038 \\
\hline \multirow{2}{*}{ Snoring (yes) } & STOP-Bang & 5 & $<0,001 \dagger$ & 2,890 & 1,673 & 4,994 \\
\hline & $\mathrm{AHI}$ & 13 & $<0,001 \dagger$ & 1,035 & 1,000 & 1,071 \\
\hline \multirow{2}{*}{ Sleepiness (yes) } & STOP-Bang & 5 & $0,003 \uparrow$ & 1,496 & 1,068 & 2,096 \\
\hline & $\mathrm{AHI}$ & 9,3 & $0,852 \dagger$ & 0,998 & 0,979 & 1,017 \\
\hline \multirow{2}{*}{ Breathing pauses during sleep (yes) } & STOP-Bang & 5 & $<0,001 \dagger$ & 2,528 & 1,596 & 4,006 \\
\hline & $\mathrm{AHI}$ & 14,7 & $<0,001 \dagger$ & 1,038 & 1,010 & 1,066 \\
\hline \multirow{2}{*}{ Systemic arterial hypertension (yes) } & STOP-Bang & 5,5 & $<0,001 \dagger$ & 2,322 & 1,492 & 3,612 \\
\hline & $\mathrm{AHI}$ & 13,1 & $0,092 \dagger$ & 1,012 & 0,995 & 1,030 \\
\hline
\end{tabular}

AHI:Apnea Hypopnea Index; *t-test for averages; †Mann-Whitney test; OR: Odds Ratio.

analyzed individually or AHI. The analysis of the diagnostic properties of the STOP-Bang questionnaire for all scores using the ROC curve, in each of OSAS subgroups alone, suggests that in the mild (AHI 5 to 14.9), moderate (AHI $\geq 15-30$ ) and severe OSAS subgroups (AHI>30), the respective STOPBang scores 3, 4 and 6 would present the best values of specificity and negative predictive value, with acceptable sensitivity (Table 4).

In the OSAS subgroups (mild, moderate and severe OSAS), no one presented a normal STOP-Bang score between 1 and 2. Eleven controls (without OSAS) had abnormal STOP-Bang score (greater than or equal to 3); their STOP-Bang scores were 3 (four individuals), 4 (five individuals), 5 (one individual) and 7 (one individual). Those 11 controls with abnormal STOP-Bang score were compared with the 11 controls with normal STOP-Bang score: control subjects with abnormal STOP-Bang score had significantly more complaints of breathing pauses during sleep (45.5 vs. $0 \%$; $p=0.035$ for Fisher's exact test), were older ( $49.1 \pm 17.6$ vs. $34.2 \pm 7.8$ years; $p=0.023$ for unpaired Student's t-test), had higher NC (median/ interquartile 25-75\%: 41/39-42 vs. 38/38-39 cm; $p=0.033$ for Mann-Whitney test) and higher values of AHI (median/ interquartile $25-75 \%: 3 / 1.7$ to 4 vs. $0.3 / 0.2$ to 1.9 ; $p=0.003$ for Mann-Whitney test).

Analysis of the best cutoff point was performed for each subgroup (control and mild, moderate, and severe OSAS) and suggested higher cutoffs that originally proposed for some subgroups. OSAS would be unlikely with STOP-Bang questionnaire score $\leq 3$, while score 5 would be likely associated with mild to moderate OSAS, and score 6 or higher would be likely associated with severe OSA (Table 5 and Figure 4). Analysis of all three groups of OSAS together showed that the ideal general cutoff for OSAS detection would be 6 (Table 5). 
Table 4. Analysis of the receiver operating characteristic curve for the STOP-Bang scores in different Apnea Hypopnea Index values.

\begin{tabular}{|c|c|c|c|c|c|c|c|}
\hline & $\begin{array}{c}\text { Score } \\
\text { STOP-Bang }\end{array}$ & $\begin{array}{l}\text { Area under } \\
\text { the curve }\end{array}$ & Sensibility & Specificity & PPV & NPV & OR \\
\hline \multirow{3}{*}{$\mathrm{AHI} 0-4,9$} & 1 & $\begin{array}{c}0,76 \\
(0,52-0,92)\end{array}$ & $\begin{array}{c}100 \\
(54,1-100)\end{array}$ & $\begin{array}{c}51,1 \\
(28,9-82,3)\end{array}$ & $\begin{array}{c}50 \\
(21,1-78,9)\end{array}$ & $\begin{array}{c}100 \\
(59-100)\end{array}$ & $\begin{array}{c}0,45 \\
(0,18-1,11)\end{array}$ \\
\hline & 2 & $\begin{array}{c}0,73 \\
(0,49-0,9)\end{array}$ & $\begin{array}{c}66,7 \\
(9,4-99,2)\end{array}$ & $\begin{array}{c}82,4 \\
(56,6-96,2)\end{array}$ & $\begin{array}{c}40 \\
(5,3-85,3)\end{array}$ & $\begin{array}{c}93,3 \\
(68,1-99,8)\end{array}$ & $\begin{array}{c}0,49 \\
(0,152-1,58)\end{array}$ \\
\hline & 3 & $\begin{array}{c}0,68 \\
(0,44-0,87)\end{array}$ & $\begin{array}{c}100 \\
(39,8-100)\end{array}$ & $\begin{array}{c}50 \\
(24,7-75,3)\end{array}$ & $\begin{array}{c}33,3 \\
(9,9-65,1)\end{array}$ & $\begin{array}{c}100 \\
(63,1-100)\end{array}$ & $\begin{array}{c}1,08 \\
(0,52-2,25)\end{array}$ \\
\hline \multirow{5}{*}{ AHI 5-14,9 } & 3 & $\begin{array}{c}0,73 \\
(0,5-0,9)\end{array}$ & $\begin{array}{c}60 \\
(14,7-94,7)\end{array}$ & $\begin{array}{c}100 \\
(79,4-100)\end{array}$ & $\begin{array}{c}100 \\
(29,2-100)\end{array}$ & $\begin{array}{c}88,9 \\
(65,3-98,6)\end{array}$ & $\begin{array}{c}0,72 \\
(0,46-1,12)\end{array}$ \\
\hline & 4 & $\begin{array}{c}0,63 \\
(0,397-0,82)\end{array}$ & $\begin{array}{c}75 \\
(19,4-99,4)\end{array}$ & $\begin{array}{c}70,6 \\
(44-89,7)\end{array}$ & $\begin{array}{c}37,5 \\
(7,3-77,9)\end{array}$ & $\begin{array}{c}92,3 \\
(64-99,8)\end{array}$ & $\begin{array}{c}1,21 \\
(0,8-1,83)\end{array}$ \\
\hline & 5 & $\begin{array}{c}0,56 \\
(0,33-0,77)\end{array}$ & $\begin{array}{c}83,3 \\
(35,9-99,6)\end{array}$ & $\begin{array}{c}46,7 \\
(21,3-73,4)\end{array}$ & $\begin{array}{c}38,5 \\
(13,9-68,4)\end{array}$ & $\begin{array}{c}87,5 \\
(47,3-99,7)\end{array}$ & $\begin{array}{c}0,891 \\
(0,63-1,27)\end{array}$ \\
\hline & 6 & $\begin{array}{c}0,72 \\
(0,48-0,89)\end{array}$ & $\begin{array}{c}50 \\
(6,8-93,2)\end{array}$ & $\begin{array}{c}100 \\
(80,5-100)\end{array}$ & $\begin{array}{c}100 \\
(15,8-100)\end{array}$ & $\begin{array}{c}89,5 \\
(66,9-98,7)\end{array}$ & $\begin{array}{c}1,376 \\
(0,87-2,17)\end{array}$ \\
\hline & 7 & $\begin{array}{c}0,51 \\
(0,28-0,73)\end{array}$ & $\begin{array}{c}50 \\
(6,8-93,2)\end{array}$ & $\begin{array}{c}100 \\
(80,5-100)\end{array}$ & $\begin{array}{c}100 \\
(15,8-100)\end{array}$ & $\begin{array}{c}89,5 \\
(66,9-98,7)\end{array}$ & $\begin{array}{c}1,00 \\
(0,6-1,7)\end{array}$ \\
\hline \multirow{2}{*}{$\mathrm{AHI} \geq 15-30$} & 4 & $\begin{array}{c}0,76 \\
(0,36-0,97)\end{array}$ & $\begin{array}{c}66,7 \\
(9,4-99,2)\end{array}$ & $\begin{array}{c}80 \\
(28,4-99,5)\end{array}$ & $\begin{array}{c}66,7 \\
(9,4-99,2)\end{array}$ & $\begin{array}{c}80 \\
(28,4-99,5)\end{array}$ & $\begin{array}{c}1,23 \\
(0,80-2,11)\end{array}$ \\
\hline & 5 & $\begin{array}{c}0,53 \\
(0,29-0,75)\end{array}$ & $\begin{array}{c}100 \\
(39,8-100)\end{array}$ & $\begin{array}{c}31,3 \\
(11-58,7)\end{array}$ & $\begin{array}{c}26,7 \\
(7,8-55,1)\end{array}$ & $\begin{array}{c}100 \\
(47,8-100)\end{array}$ & $\begin{array}{c}1,03 \\
(0,67-1,58)\end{array}$ \\
\hline \multirow{4}{*}{$\mathrm{AHI}>30$} & 3 & $\begin{array}{c}0,678 \\
(0,45-0,87)\end{array}$ & $\begin{array}{c}100 \\
(15,8-100)\end{array}$ & $\begin{array}{c}50 \\
(26-74)\end{array}$ & $\begin{array}{c}18,2 \\
(2,3-51,8)\end{array}$ & $\begin{array}{c}100 \\
(66,4-100)\end{array}$ & $\begin{array}{c}0,968 \\
(0,89-1,06)\end{array}$ \\
\hline & 4 & $\begin{array}{c}0,53 \\
(0,29-0,75)\end{array}$ & $\begin{array}{c}100 \\
(39,8-100)\end{array}$ & $\begin{array}{c}31,3 \\
(11-58,7)\end{array}$ & $\begin{array}{c}26,7 \\
(7,8-55,1)\end{array}$ & $\begin{array}{c}100 \\
(47,8-100)\end{array}$ & $\begin{array}{c}0,991 \\
(0,94-1,05)\end{array}$ \\
\hline & 5 & $\begin{array}{c}0,58 \\
(0,34-0,79)\end{array}$ & $\begin{array}{c}100 \\
(54,1-100)\end{array}$ & $\begin{array}{c}28,6 \\
(8,4-58,1)\end{array}$ & $\begin{array}{c}37,5 \\
(15,2-64,6)\end{array}$ & $\begin{array}{c}100 \\
(29,2-100)\end{array}$ & $\begin{array}{c}0,934 \\
(0,9-1,07)\end{array}$ \\
\hline & 6 & $\begin{array}{c}0,678 \\
(0,43-0,86)\end{array}$ & $\begin{array}{c}50 \\
(11,8-88,2)\end{array}$ & $\begin{array}{c}92,9 \\
(66,1-99,8)\end{array}$ & $\begin{array}{c}75 \\
(13,2-99,8)\end{array}$ & $\begin{array}{c}81,2 \\
(54,4-96)\end{array}$ & $\begin{array}{c}0,980 \\
(0,93-1,03)\end{array}$ \\
\hline
\end{tabular}

PPV: positive predictive value; NPV: negative predictive value; OR: Odds Ratio; AHI: Apnea Hypopnea Index.

Table 5. Analysis of the receiver operating characteristic curve for prediction of STOP-Bang questionnaire cutoff points: analysis with the four Apnea Hypopnea Index groups and the three Apnea Hypopnea Index cutoff points.

\begin{tabular}{|c|c|c|c|c|c|c|c|}
\hline AHI groups & $\begin{array}{l}\text { Area under } \\
\text { the curve }\end{array}$ & Sensibility & Specificity & PPV & NPV & OR & $\begin{array}{l}\text { Cutoff points } \\
\text { STOP-Bang }\end{array}$ \\
\hline $0-4,9$ & $\begin{array}{c}77,6 \\
(55-92,4)\end{array}$ & $\begin{array}{c}99,9 \\
(47,8-100)\end{array}$ & $\begin{array}{c}58,8 \\
(32,9-81,6)\end{array}$ & $\begin{array}{c}65,4 \\
(24,2-94)\end{array}$ & $\begin{array}{c}90,8 \\
(63,4-99,5)\end{array}$ & $\begin{array}{c}1,83 \\
(1,03-3,6)\end{array}$ & 3 \\
\hline $5-14,9$ & $\begin{array}{c}57,2 \\
(34,1-78,2)\end{array}$ & $\begin{array}{c}83,3 \\
(35,9-99,6)\end{array}$ & $\begin{array}{c}53,3 \\
(26,6-78,7)\end{array}$ & $\begin{array}{c}54,3 \\
(24,4-82,1)\end{array}$ & $\begin{array}{c}82,8 \\
(42,4-98,9)\end{array}$ & $\begin{array}{c}2,76 \\
(1,2-8,5)\end{array}$ & 5 \\
\hline$\geq 15-30$ & $\begin{array}{c}53,3 \\
(17,9-86,4)\end{array}$ & $\begin{array}{c}66,7 \\
(9,4-99,2)\end{array}$ & $\begin{array}{c}60 \\
(14,7-94,7)\end{array}$ & $\begin{array}{c}87 \\
(27,9-100)\end{array}$ & $\begin{array}{c}31 \\
(0,6-89,6)\end{array}$ & $\begin{array}{c}5,11 \\
(1,5-61)\end{array}$ & 5 \\
\hline$>30$ & $\begin{array}{c}67,9 \\
(43,6-86,6)\end{array}$ & $\begin{array}{c}50 \\
(11,8-88,2)\end{array}$ & $\begin{array}{c}92,9 \\
(66,1-99,8)\end{array}$ & $\begin{array}{c}84,1 \\
(31,8-99,8)\end{array}$ & $\begin{array}{c}71,1 \\
(41,6-91,4)\end{array}$ & $\begin{array}{c}6,26 \\
(2,4-22,1)\end{array}$ & 6 \\
\hline$\geq 5$ & $\begin{array}{c}69,5 \\
(54,7-81,8)\end{array}$ & $\begin{array}{c}90 \\
(55,5-99,7)\end{array}$ & $\begin{array}{c}46,2 \\
(30,1-62,8)\end{array}$ & $\begin{array}{c}36,6 \\
(19,8-56)\end{array}$ & $\begin{array}{c}93 \\
(70,8-99,7)\end{array}$ & $\begin{array}{c}1,98 \\
(1,1-3,6)\end{array}$ & 6 \\
\hline$\geq 15$ & $\begin{array}{c}70,7 \\
(50,6-86,3)\end{array}$ & $\begin{array}{c}71,4 \\
(29-96,3)\end{array}$ & $\begin{array}{c}66,7 \\
(43-85,4)\end{array}$ & $\begin{array}{c}51,7 \\
(22,4-80,2)\end{array}$ & $\begin{array}{c}82,4 \\
(54,5-96,7)\end{array}$ & $\begin{array}{c}3,46 \\
(1,1-11,4)\end{array}$ & 6 \\
\hline$\geq 30$ & $\begin{array}{c}67,9 \\
(43,6-86,6)\end{array}$ & $\begin{array}{c}50 \\
(11,8-88,2)\end{array}$ & $\begin{array}{c}92,9 \\
(66,1-99,8)\end{array}$ & $\begin{array}{c}84,1 \\
(31,8-99,8)\end{array}$ & $\begin{array}{c}71,1 \\
(41,6-91,4)\end{array}$ & $\begin{array}{c}6,26 \\
(2,4-22,1)\end{array}$ & 6 \\
\hline
\end{tabular}

AHI: Apnea Hypopnea Index; PPV: positive predictive value; NPV: negative predictive value; OR: Odds Ratio. 

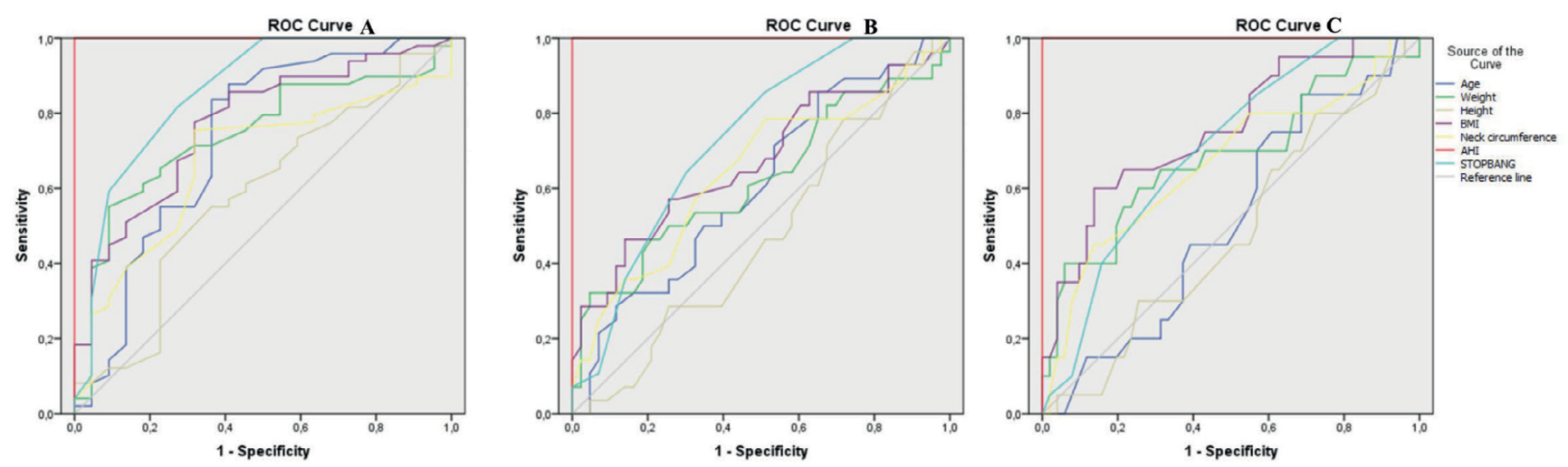

ROC: receiver operating characteristic curve; BMI: body mass index; AHI: Apnea Hypopnea Index.

Figure 4. Areas under the curve for the STOP-Bang questionnaire score and its components. (A) apnea-hypopnea index $\geq 5$;

(B) apnea-hypopnea index $\geq 15$; (C) apnea-hypopnea index $\geq 30$.

\section{DISCUSSION}

The OSAS sample assessed in this study was similar to that described in the literature, with a predominance of men in the fifth decade of life, with higher values of NC, weight and BMI, variables independently associated with the development of the syndrome ${ }^{1,2,15}$. Similarly, the group with moderate and severe OSAS had more breathing pauses during sleep and snoring, whose presence can increase by 11 times the chance of OSAS ${ }^{16}$. Greater number of reported complaints occurs as AHI increases, what explains why our mild OSAS group had more breathing pauses during sleep, but no more snoring than controls2.

In this sample, daytime sleepiness and hypertension were not more frequent in the group with OSAS compared with the control group, and may have impacted less in the STOP-Bang final score, which is also evidenced in the lower odds ratio values related to these two variables in this study. Regarding daytime sleepiness, previous studies in Brazil showed that $29.5 \%$ of volunteers who presented with an AHI between 5 and 15 did not have any complaints, as well as about $25 \%$ of those with AHI above $15^{2}$. Moreover, Weaver et al. drew attention to the low interaction between polysomnography and self-reported symptoms ${ }^{17}$.

Our sample had a predominance of men, who can present less hypertension than women with OSAS, what could explain the lower frequency of hypertension in our sample ${ }^{6}$. The positive association between STOP-Bang, AHI, weight, $\mathrm{NC}$ and BMI confirms data that point the close link of obesity with OSAS, especially central obesity, due to the distribution of non-homogeneous fat ${ }^{15,18,19}$. The BMI reflects an overall increase in body weight relative to height, while the $\mathrm{NC}$ reflects fat involving the pharyngeal portion of the upper airway, with higher correlation with OSAS than BMI ${ }^{15,18,19}$. Our data confirm the link of STOP-Bang questionnaire with the AHI and the main risk factors.

OSAS has gained attention among health authorities in many countries, encouraging researches to establish its prevalence, individual consequences and social cost, as well as the best way to perform the diagnosis and treatment ${ }^{20}$. The screening questionnaires have become important in detection of patients with undiagnosed OSAS, especially if they are easy to apply ${ }^{21}$. The ideal screening tool should have high sensitivity and specificity at the same cutoff, but this is a very rare occurrence and in most cases there is an imbalance between them, i.e., as the cutoff value moves to increase the specificity, sensitivity decreases ${ }^{22}$. With a higher specificity, there would be few false positives and healthy people would not be misdiagnosed with OSAS; but, with higher sensitivity, there would be few false negatives and patients with the disease would not be labeled as healthy - then, a higher sensitivity would be more relevant to the choice of OSAS screening tools, minimizing the consequences of the lack of diagno$\operatorname{sis}^{22,23}$. In this sense, the STOP-Bang has become a widely used tool in OSAS detection, demonstrating high methodological quality and good consistency to identify patients at different levels of OSAS severity 2,8,9,10,11,20,21,22. Due to worldwide interest, currently STOP-Bang questionnaire is used in various translated versions as a more accurate screening method, but some studies have employed the original version without cultural adaptations and validations, thereby affecting their properties, specificity, and sensitivity due to errors of interpretation ${ }^{10,22}$.

In studies conducted in sleep clinics, with the cutoff point of 3, the sensitivity of STOP-Bang ranged from 81-98\%, negative predictive value (NPV) ranged from $35-97 \%$ and the specificity was between $10-76 \%$ in OSAS groups ${ }^{11,21,23,24,25,26,27,28,29}$. For this cutoff point of 3 in the STOP-Bang, our analysis of the Brazilian sample with mild OSAS (AHI 5 to 14.9) showed lower values of sensitivity (60\%), similar NPV (88.9\%) and higher specificity (100\%). In addition, our analysis suggested higher cutoff points for groups with moderate (AHI $\geq 15-30$ ) and severe (AHI>30) OSAS, respectively, 4 and 6, which is in line with studies that indicate high probability of OSAS with more than five positive answers in the STOP-Bang ${ }^{21}$. 
With the same groups of previous studies (AHI $\geq 5, \mathrm{AHI} \geq 15$ and $A H I \geq 30$ ), our analysis to predict the cutoffs points in the STOP-Bang questionnaire for OSAS suggests higher cutoffs than originally indicated by Chung et al. ${ }^{10}$. With the cutoff value of six, if the three subgroups are included (AHI $\geq 5$ ), the sensitivity, specificity and NPV would be similar to previous studies ${ }^{10}$. With only the moderate/severe OSAS subgroups (AHI $\geq 15$ ) included for a cutoff point of six, just the sensitivity would be slightly lower than in previous studies ${ }^{10}$. And, if we analyze only the severe OSAS subgroup (AHI $\geq 30$ ) for a cutoff point of six, the sensitivity would be lower and the specificity higher ${ }^{10}$. Our data are similar to those from Farney et al., that assessed 1,426 patients of clinical sleep disorders, and reported a $85.1 \%$ probability of having an $\mathrm{AHI} \geq 5$ if the STOP-Bang score is greater than 3, and 90, 93 and over 95\% for scores 4,5 and 6 , respectively ${ }^{30}$. The presence of abnormal STOP-Bang in controls suggests the need for cutoffs adapted to our reality.

The STOP-Bang instrument presented different versions developed in order to try to improve the diagnosis of OSAS and to discriminate the subgroups with mild, moderate and severe OSAS, in addition to adapting it to constitutional anatomical differences of patients from other countries ${ }^{5,8,10,11,22.29}$. There is another validated version for the Portuguese language spoken in Brazil, which incorporates different values of cervical circumference (greater than $43 \mathrm{~cm}$ for men and $41 \mathrm{~cm}$ for women), with final scores ranging from low and moderate to high risk of OSAS; this version had a slightly higher sensitivity (83.5\%) for the Brazilian sample, but a much lower specificity (45.5\%) than the version used for $\mathrm{us}^{31,32}$. Thus, our proposal of different cutoff points for OSAS in general, and for the mild, moderate and severe subtypes, could improve the performance of the instrument in our population.

Our study has limitations compared to previous studies conducted in sleep clinics, related to the relatively small sample size to evaluate the usefulness of the STOP-Bang to identify OSAS. The number of patients was based on a correlation of at least $50 \%$ of the questionnaire with the polysomnography. A higher number of patients could increase the correlation between STOP-Bang and polysomnography. Another limitation is that the number of patients in the moderate group was on average lower than in the other groups (control, mild and severe). On the other hand, this study has some advantages, such as its prospective design specifically for this analysis, the fact that all participants completed the questionnaires and underwent polysomnography in a short period of time and in excellent conditions during a full night's sleep. Moreover, the clinical team and the sleep study analysis technique did not know the result of the STOP-Bang questionnaire of each patient.

The version of the STOP-Bang questionnaire - translated, adapted and validated in a sample of Brazilian - identified patients with OSAS, but with lower sensitivity and higher specificity compared to previous international studies. The use of different cutoff points in the Brazilian version of the STOP-Bang questionnaire, compared to the cutoff point of three originally proposed, improved the performance for detection of patients with more severe OSAS.

\section{References}

1. No authors listed. Sleep-related breathing disorders in adults: recommendations for syndrome definition and measurement techniques in clinical research. The Report of an American Academy of Sleep Medicine Task Force. Sleep. 1999 Aug;22(5):667-89.

2. Tufik S, Santos-Silva R, Taddei JA, Bittencourt LR. Obstructive sleep apnea syndrome in the Sao Paulo Epidemiologic Sleep Study. Sleep Med. 2010 May;11(5):441-6. https://doi.org/10.1016/j. sleep.2009.10.005

3. Young T, Evans L, Finn L, Palta M. Estimation of the clinically diagnosed proportion of sleep apnea syndrome in middle-aged men and women. Sleep. 1997 Sep;20(9):705-6. https://doi.org/10.1093/sleep/20.9.705

4. American Academy of Sleep Medicine. International classification of sleep disorders. Diagnostic and coding manual (ICSD-2). 2nd ed. Westchester, IL: American Academy of Sleep Medicine; 2005.

5. Pavarangkul T, Jungtrakul T, Chaobangprom P, Nitiwatthana L, Jongkumchok W, Morrakotkhiew W, et al. The Stop-Bang Questionnaire as a screening tool for obstructive sleep apneainduced hypertension in asian population. Neurol Int. 2016 Apr;8(1):6104. https://doi.org/10.4081/ni.2016.6104

6. Alotair H, Bahammam A. Gender differences in Saudi patients with obstructive sleep apnea. Sleep Breath. 2008 Nov;12(4):323-9. https://doi.org/10.1007/s11325-008-0184-8

7. Lux L, Boehlecke B, Lohr KN. Effectiveness of portable monitoring devices for diagnosing obstructive sleep apnea: update of a systematic review. Rockville (MD): Agency for Healthcare Research and Quality (US); 2004. Available from: https://www.ncbi.nlm.nih.gov/ books/NBK299250/

8. Abrishami A, Khajehdehi A, Chung F. A systematic review of screening questionnaires for obstructive sleep apnea. Can J Anaesth. 2010 May;57(5):423-38. https://doi.org/10.1007/s12630-010-9280-x

9. Silva GE, Vana KD, Goodwin JL, Sherrill DL, Quan SF. Identification of patients with sleep disordered breathing: comparing the fourvariable screening tool, STOP, STOP-Bang, and Epworth Sleepiness Scales. J Clin Sleep Med. 2011 Oct;7(5):467-72. https://doi. org/10.5664/JCSM.1308

10. Chung F, Yegneswaran B, Liao P, Chung SA, Vairavanathan S, Islam S, et al. STOP questionnaire: a tool to screen patients for obstructive sleep apnea. Anesthesiology. 2008 May;108(5):812-21. https://doi. org/10.1097/ALN.0b013e31816d83e4

11. Nagappa M, Liao P, Wong J, Auckley D, Ramachandran SK, Memtsoudis S. Validation of the STOP-Bang Questionnaire as a screening tool for obstructive sleep apnea among different populations: a systematic review and meta-analysis. PLoS One. 2015 Dec;10(12):e0143697. https://doi.org/10.1371/journal.pone.0143697

12. Iber C, Ancoli-Israel S, Chesson Jr A, Quan S. The AASM manual for the scoring of sleep and associated events: rules, terminology and technical specifications. Westchester, IL: American Academy of Sleep Medicine; 2007. 
13. Coelho FM, Pradella-Hallinan M, Palombini L, Tufik S, Bittencourt LRA. The STOP-BANG questionnaire was a useful tool to identify OSA during epidemiological study in São Paulo (Brazil). Sleep Med. 2012 Apr;13(4):450-1. https://doi.org/10.1016/j.sleep.2012.01.008

14. McGraw KO, Wong SP. A common language effect-size statistic. Psychol Bull. 1992;111(2):361-365. https://doi.org/10.1037/00332909.111.2.361

15. Dancey DR, Hanly PJ, Soong C, Lee B, Shepard J Jr, Hoffstein V. Gender differences in sleep apnea: the role of neck circumference. Chest. 2003 May;123(5):1544-50. https://doi.org/10.1378/ chest.123.5.1544

16. Silva HGV, Moreira ASB, Santos VR, Santos SO, Rêgo AFB. Factors associated with obstructive sleep apnea severity: obesity and excessive daytime sleepiness. Rev Bras Cardiol. 2014 Mar/ Apr;27(2):76-82.

17. Weaver EM, Kapur V, Yueh B. Polysomnography vs self-reported measures in patients with sleep apnea. Arch Otolaryngol Head Neck Surg. 2004 Apr;130(4):453-8. https://doi.org/10.1001/ archotol.130.4.453

18. Peppard PE, Young T, Palta M, Dempsey J, Skatrud J. Longitudinal study of moderate weight change and sleep-disordered breathing. JAMA. 2000 Dec;284(23):3015-21. https://doi.org/10.1001/ jama.284.23.3015

19. Isono S. Obstructive sleep apnea of obese adults: pathophysiology and perioperative airway management. Anesthesiology. 2009 Apr;110(4):908-21. https://doi.org/10.1097/ALN.0b013e31819c74be

20. Vasu TS, Doghramji K, Cavallazzi R, Grewal R, Hirani A, Leiby B, et al. Obstructive sleep apnea syndrome and postoperative complications: clinical use of the STOP-BANG questionnaire. Arch Otolaryngol Head Neck Surg. 2010 Oct;136(10):1020-4. https://doi.org/10.1001/ archoto. 2010.1020

21. Reis R, Teixeira F, Martins V, Sousa L, Batata L, Santos C, et al. Validation of a Portuguese version of the STOP-Bang questionnaire as a screening tool for obstructive sleep apnea: Analysis in a sleep clinic. Rev Port Pneumol. 2015 Mar/Apr;21(2):61-8. https://doi. org/10.1016/j.rppnen.2014.04.009

22. Chung F, Yang Y, Brown R, Liao P. Alternative scoring models of STOP-Bang questionnaire improve specificity to detect undiagnosed obstructive sleep apnea. J Clin Sleep Med. 2014 Sep;10(9):951-8. https://doi.org/10.5664/jcsm.4022

23. Ha SCN, Lee DLY, Abdullah VJ, van Hasselt CA. Evaluation and validation of four translated Chinese questionnaires for obstructive sleep apnea patients in Hong Kong. Sleep Breath. 2014 Dec;18(4):715-21. https://doi.org/10.1007/s11325-013-0889-1

24. Kim B, Lee EM, Chung YS, Kim WS, Lee SA. The utility of three screening questionnaires for obstructive sleep apnea in a sleep clinic setting. Yonsei Med J. 2015 May;56(3):684-90. https://doi. org/10.3349/ymj.2015.56.3.684

25. Sadeghniiat-Haghighi K, Montazeri A, Khajeh-Mehrizi A, Ghajarzadeh M, Alemohammad ZB, Aminian O, et al. The STOP-BANG questionnaire: reliability and validity of the Persian version in sleep clinic population. Qual Life Res. 2015 Aug;24(8):2025-30. https://doi. org/10.1007/s11136-015-0923-9

26. Boynton G, Vahabzadeh A, Hammoud S, Ruzicka DL, Chervin RD. Validation of the STOP-BANG Questionnaire among patients referred for suspected obstructive sleep apnea.J Sleep Disord Treat Care. 2013 Sep;2(4):10.4172/2325-9639.1000121. https://doi. org/10.4172/2325-9639.1000121

27. BaHammam AS, Al-Aqeel AM, Alhedyani AA, Al-Obaid GI, Al-Owais MM, Olaish AH. The Validity and Reliability of an Arabic Version of the STOP-Bang Questionnaire for Identifying Obstructive Sleep Apnea. Open Respir Med J. 2015;9:22-9. https://doi. org/10.2174/1874306401509010022

28. Vana KD, Silva GE, Goldberg R. Predictive abilities of the STOP-Bang and Epworth Sleepiness Scale in identifying sleep clinic patients at high risk for obstructive sleep apnea. Res Nurs Health. 2013 Feb;36(1):84-94. https://doi.org/10.1002/nur.21512

29. Ong TH, Raudha S, Fook-Chong S, Lew N, Hsu AA. Simplifying STOP-BANG: use of a simple questionnaire to screen for OSA in an Asian population. Sleep Breath. 2010 Dec;14(4):371-6. https://doi. org/10.1007/s11325-010-0350-7

30. Farney RJ, Walker BS, Farney RM, Snow GL, Walker JM. The STOPBang equivalent model and prediction of severity of obstructive sleep apnea: relation to polysomnographic measurements of the apnea/hypopnea index.J Clin Sleep Med. 2011 Oct;7(5):459-65. https://doi.org/10.5664/JCSM.1306

31. Fonseca LB, Silveira EA, Lima NM, Rabahi MF. STOP-Bang questionnaire: translation to Portuguese and cross-cultural adaptation for use in Brazil.J Bras Pneumol. 2016 Jul/Aug;42(4):26672. https://doi.org/10.1590/S1806-37562015000000243

32. Duarte RLM, Fonseca LBM, Magalhães-da-Silveira FJ, Silveira EAD, Rabahi MF. Validation of the STOP-Bang questionnaire as a means of screening for obstructive sleep apnea in adults in Brazil. J Bras Pneumol. Nov-Dec 2017;43(6):456-63. https://doi.org/10.1590/ S1806-37562017000000139 